\title{
The Impact of the Covid-19 Pandemic in Teaching and Learning Activity
}

\author{
Eka Arifianti Saputri ${ }^{1 *}$, Fauzi Miftakh, Yogi Setia Samsi \\ University of Singaperbangsa Karawang \\ ekaarifianti.saputri@gmail.com
}

\begin{abstract}
The emergence of Covid-19 some time ago had a huge impact on the world of education. Currently, the pandemic is still not over, but these difficulties cannot stop the nation's obligation to study and attend school. There have been many ways that have been done by the government, educators, and participants in getting around the best way to study during a pandemic. The government also decided that teaching and learning activities be carried out online so that students and teachers can avoid Covid-19. However, studying online is not as easy as it seems. Covid-19 has an effect that is felt by all educational groups, especially students. This study discusses the effects of Covid-19 on all students and learning personnel in teaching and learning activities. In addition, this article also provides an overview of how the proper teaching and learning process should be carried out so that the benefits of the process can be received equally from both parties.
\end{abstract}

Key words: the effect of covid-19, teaching and learning, online learning, positive impact, negative impact

\section{A. INTRODUCTION}

At this time, the world was shocked by the prolonged uninvited presence of the pandemic, namely Covid-19. The disease outbreak, which was allegedly started to plague in 2019, has now spread to almost the entire world. It is not certain when exactly this outbreak will disappear. There have been many fatalities who have died from this virus, and often many people have been exposed to the virus but 
have no symptoms of the disease. This is really very dangerous considering the very fast transmission of this disease from human to human. In addition, there has not been found a drug that is lucky to cure this disease. To suppress the increasing number of Covid-19, governments in every world have decided that every citizen should carry out policies that have been made in such a way as to protect them from the spread of this corona virus. Citizens are asked to keep their distance, use protection such as masks, always wash their hands, and carry a hand sanitizer wherever they go. Residents are also advised to stay at home and not go out if there is no urgent need.

Indirectly, Covid-19 greatly suppresses the continuity of habits that we often do. Activities began to be limited due to Covid-19. There are so many fields that in the end do not work as they should, such as economy, social, and education. Covid-19 which has hit almost every region in the world has caused limitations in all aspects, including education. Bayham and Fenichel (2020) explain that this outbreak has an impact on the reasons why schools and other educational intuitions are closed to avoid physical contact of every human being. Education, which is basically a country's obligation, must be temporarily suspended due to Covid-19. Fitria (2020) explained that the ministry of education in Indonesia issued a policy to temporarily close schools. However, this termination cannot be done forever considering that education is very important to advance a nation. It is feared that there will be backwardness if education must be stopped for the progress of a nation. For this reason, the government is racking its brains about the programs so that education can continue to be carried out even in conditions of limitations and difficulties due to Covid-19.

The government also decided that education should still be implemented, but it should be done online. Students are asked to study at home without coming to 
school as usual. In addition, teachers must also teach students online. Simamora (2020) explains that teaching and learning activities that are usually carried out face-to-face have turned into online learning with the help of various online learning applications. For that, technology such as cellphones, laptops and the like are needed in order to support student learning and teaching activities. In some cases, students who live in non-emergency zones are allowed to come to school, but still implement health protocols. In addition, the number of students who attend must also be limited, bearing in mind that there are no crowds and still have to enforce social distancing policies from the government. However, this has a significant impact on student development. At first, students feel a little bit difficult due to this distance learning, but they try to adapt to a new way of learning which they inevitably have to do.

The same thing was said by Corbera, Anguelovski, Honey-Rosés and Ruiz-Mallén (2020) that all parties in education have to work at home due to Covid-19 forces. Students are asked to study at home each with the help of online learning applications as their learning media. Apart from having difficulty adapting, the rest also experienced mental and physical weakness. They are isolated and just stay at home. Students who tend to always want to study in groups for discussion, now it is impossible to do it. As social beings, no human being can survive without interaction with their social environment (Hawkley \& Cacioppo, 2010). Istiqomah, Meilani, \& Khoiriyah (2020) said that human as social beings need to interact with other people, it will be a psychological burden if they cannot do this as their need. This physical restriction really makes human get mental health problem Cao, Fang, Hou, Han, Xu, Dong \& Zheng (2020).

It can be seen, the effects of Covid-19 refer more to the psychological level of students. Sometimes they find it difficult and at the end, they often complain 
about learning online. Apart from that, their responsibility as a teacher is also questioned in the learning process. The teacher as a guide is expected to provide the best way in the teaching and learning process so that it will not burden the students. The two participants should understand each other's situation so that they both get positive and beneficial things, without either party feeling aggrieved.

Then the impact of Covid-19, which has an impact on changing the way learning goes online, has a major impact on students' mental development. According to $\mathrm{Li}$ and Leung (2020), Covid-19 has had an adverse effect on students' mental health, such as academics, limited interactions, health-related fears, and loss of normal routines. This is because they are faced with various kinds of problems at the same time. The existence of online learning may reduce the number of Covid-19 spread, but they learn super extra to try to overcome physical and mental health problems, and feelings of isolation due to studying online during this Pandemic. (Raaper \& Brown, 2020).

\section{B. RESEARCH METHOD}

This scientific paper is a research that explain about the impact of Covid-19 in teaching learning activity. It also explained the mental condition of students, teachers, and the impact that Covid-19 has had during the teaching and learning process. For data collection techniques, every single source that the writer use is from various journals and the results of the development of the writer's minds. Various journals that we get as references are from identified and quality journals. And it is processed with data analysis techniques (non - statistics analysis) where this technique provides facts without statistical calculations and reads data that has previously been written by other authors. The method that the author use is descriptive method with library research because the author used data sources from journal, books, writings concerned with the discussion. According to 
Sugiyono (2005:21), descriptive method is a method used to draw up and analyze a research result but not used for broader conclusion.

\section{FINDINGS AND DISCUSSION}

\section{Findings}

Learning carried out online as a result of the Corona virus attacking the world seems to have a big impact on all fields, including education. Education that was originally carried out in school face-to-face has now been replaced by a new policy, which is carried out online from each home. This was enforced by the government in order to reduce the number of the spread of Covid-19 which was increasing significantly every day. As a result of Covid-19, almost all teaching and learning activities were carried out online. Ferdiansyah, Suspiastutik, Angin (2020) explained that online learning is something new for students. Students are required to continue to follow the existing learning as usual, but with the implications of new learning methods. Unconsciously, Covid-19 guides the learning process to be carried out mostly in an independent way. The distance and restrictions on going to school impose limits on students to learn. If while still studying in school, learning can be done using various methods, but in virtual learning, the learning process is very limited. However, overall, at least e-learning has helped students to continue learning at home during Covid-19 (Ichsan, Rahmayanti, Purwanto, Sigit, Irwandani, Ali, Susilo, Kurniawan, Rahman, 2020).

The influence of Covid-19 in the teaching and learning process emphasizes the aspects of how it affects students' personality and psychology in learning. Covid19, which forces students to study independently without direct guidance by educators as usual, of course has an impact on the nature of their personality. In addition, Covid-19 also has an impact on the condition of students at home. 
Teachers tend not to know students' abilities in learning, because learning is carried out remotely.

In addition, how the behavior and treatment provided by educators during the Covid-19 learning period determines the success of students in online learning. It should be emphasized that Covid-19 does not make teachers more relaxed in teaching, sometimes this limitation also increases the teaching burden, which if the teacher himself is overwhelmed by the current situation, it will be ensured that students will be more overwhelmed and not optimally learn. Therefore, the treatment and conditions of teachers also affect the effectiveness of teacher learning in pandemic conditions.

The pandemic, which never ends day after day, has made many students and teachers despair in the learning process. The lessons are believed to be increasingly difficult to understand because of the limitations caused by Covid-19. There are many negative sides that arise from this problem, such as learning that must be done online, lack of learning facilities and infrastructure, lack of joint contributions when doing assignments, and a decreased sense of solidarity due to too often doing assignments independently. However, there are times when we must be able to take lessons from every disaster that occurs and make it a positive thing that can increase the effectiveness of learning in a pandemic like today. Learning with e-learning makes us more able to renovate and be more creative. In addition, the support of parents and teachers is the key to success in virtual independent learning. 


\section{Discussion}

\subsection{The Impact of Corona on Students' Feelings in the Teaching and Learning Process}

Indirectly, Covid-19 has an impact on the learning process of students. This relates to their psychological condition and the emotions they feel while studying during Covid-19. Covid-19 has worsened students' mental health due to academic disruption, limited interactions, health-related fears, and the loss of normal routines ( $\mathrm{Li}$ and Leung, 2020). Many students initially felt happy to be able to study at home when they found out that their school would be temporarily closed due to the Covid-19 outbreak. But over time, online learning turned out to be more tiring and harder to do. They miss the time when they do assignments by having direct discussion with friends, miss the lessons the teacher gives in front of the class, and miss the library room full of textbook references that can ease their assignments. Learning at home in a virtual way gives them boundaries to socialize. According to Cao, Fang, Hou, Han, Xu, Dong \& Zheng (2020), physical restriction can cause mental health problems. In addition, this limitation means that teaching materials can only be found on the internet, and one cannot ask directly to the teacher or go to the library to read books.

In addition, what is most overwhelming is the multitude of tasks and the pile up. It is not uncommon for students to sleep late at night to do their assignments with very short deadlines. This of course makes students stress and always blames the teacher and the situation. They need to socialize and discuss while studying, which online learning makes them locked up and unable to discuss with their friends. Of course, this is very stressful as explained by Istiqomah, Meilani, \& Khoiriyah (2020), that this is a huge psychological burden because the human need as a social being to interact with other people cannot be fulfilled. In addition, online lectures also require extra fees to buy internet quota for surfing for material 
on Google and the like. The habit of students who often sleep late because they make assignments makes them extremely tired both psychologically and physically. They are susceptible to disease and the most influential thing is the health of the eyes, who every day have to stare at the computer screen for too long for virtual classes.

However, the thing that most students who do online school feel the most about is the lack of knowledge they get from learning. The teacher only gives assignments without paying attention to the students mastering the learning or not. What happens is that students only do assignments and collect them, they no longer care about the knowledge they receive. In addition, there are times when even though learning must be carried out online, they still do it synchronously so that learning can run properly.

\subsection{The impact of Corona on teacher treatment in the teaching and learning process}

The rise in cases of the spread of Covid-19 has made teaching and learning activities diverted from being face-to-face, now it must be done virtually, making teachers rack their brains to find solutions to these problems. Much speculation is milling about the role of teachers in online learning. There are several teachers who are fully responsible for giving all their attention to the teaching and learning process. And several others have come out of their responsibility to convey the material properly and correctly to students. This type of teacher only gives assignments to students without ever knowing the progress of their students. It is very unfortunate that during this pandemic, students should be taught maximally considering the conditions that are not conditional for learning. Maybe some teachers believe that online learning can build students 'learning methods and help them meet their learning needs (De Paepe, Zu and Depryck, 2018), but students 
still need teacher guidance, however, so that teachers must prioritize students' mastery of learning rather than just giving them assignments.

Basically, it is understandable that teaching in a pandemic condition has its own challenges for teachers. Many of their focuses are divided, sometimes they have to face problems around education not only on students, but with parents as well. Many parents and students themselves complain about the mechanism that runs only around the assignment without any feedback from the teacher. This can happen because teachers are not accustomed to learning systems that have turned online. There are several things that become obstacles in the implementation of online education during the pandemic, such as teacher-centered learning and gaps between teachers and students so that learning is not optimal (Moorehouse, 2020). In addition, online learning is also considered less effective based on the way of assessment, material delivery and the relationship between teachers and students (Dyment, Downing, Hill and Smith, 2017). So it can be concluded that some complaints from students to teachers occur because teachers have not been able to adapt to online learning itself.

Teachers who are facilitators of knowledge for students must try to be as creative as possible to create learning methods that are suitable to be applied when learning online. Actually, the teacher's job is not only to transfer knowledge only to students, but they also have to teach the values of manners and attitudes which cannot be done with the help of technology. Teachers must go directly to see student progress in learning. Besides that, the difficulty of learning online that must be done by the teacher is a challenge that must be done. Teachers can be better prepared to do online learning by taking online learning technical training (Karkar-Esperat, 2018) so that they are more familiar with how to teach online which is quite new to do. 


\subsection{Positive and Negative Impacts were Learned During the Covid-19 Pandemic}

There are various things and phenomena that were considered in the teaching and learning process in the Covid-19 era. Many think that Covid-19 only has a negative effect in all spheres and areas of life, as expressed by Li and Leung (2020) that this pandemic has a negative impact on the mental health of students. However, if we are humans who know how to be grateful and take valuable lessons from this disaster, of course there will be a positive impact that we can feel.

It is possible that during this pandemic, all activities will be limited. All fields such as education, economy, and others are not running optimally as before. Moreover, in the world of education, teaching and learning activities aimed at advancing and educating the nation are not running optimally. Almost all schools in Indonesia have been temporarily closed and conducted online. The absence of students from going to school leads them to always study independently and sometimes have difficulty learning. In addition, they have less direct interaction with their peers because they are self-taught in their own homes. Learning that should be maximized by way of discussion becomes more difficult. According to Cao, Fang, Hou, Han, Xu, Dong \& Zheng (2020) physical restriction causes various problems for the mental health of students. So there is a reduction in interactions due to Covid-19, many of them prolonged stress.

Students complain more often about difficulties when studying online. What should be considered about online learning is that not all students in Indonesia have the same brain capacity. For those who feel they are able to receive material 
online and without a very clear explanation from the teacher, they will probably feel fine with how to learn online. But for those who are less able to receive lessons online, maybe this is really burdensome for them. Apart from that, from an economic perspective, not all students in Indonesia have the same economic situation. There are still some underprivileged parties who do not have adequate technological tools to help them carry out online learning. For this reason, the government must be able to open its eyes more and find solutions to the obstacles that some students in Indonesia feel. After all, all are entitled to equal education for the sake of advancing this nation.

The positive impact that we can feel during this pandemic is our time to rest longer. If the teacher understands the student's situation and does not burden them with a lot of various tasks, then students and teachers can more freely rest. They don't need to go to school and just sit at home to start their lessons. In addition, their time with their family is longer. For students who are nomads, this is a boon for them because they can stay with their families longer. In addition, all forms of learning that are carried out online make parties more aware of technology. The use of technological devices such as computer gadgets and others has become their daily diet, which in the end they can better master the use of technology due to online learning.

\subsection{Maximizing the teaching and learning process during Covid-19}

Because Covid-19 is currently hitting, forcibly the teaching and learning process and all educational processes are carried out virtually. Learning is carried out online with the help of various types of online applications used for learning, such as Zoom, Google Meet, Google Classroom and the like. The government has also begun to open its eyes that online learning, of course, requires a lot of money to buy internet quotas for the learning process. The government has provided free 
internet quota for students throughout Indonesia to do face time while studying. There are two types of internet quota provided by the government, namely the learning quota which is used specifically for online meeting applications such as Zoom, Google Meet and the like, and is given a regular quota to access the internet to find learning resources on Google and the like. However, the provision of quotas is deemed imbalance because the provision of a special quota for meetings is far more than the regular quota. There may be fears from the government that the regular quotas will be misused by students. However, the quota is too small if used within a month, considering that online classes are conducted almost every day every week.

To maximize the learning process, teachers need to make more efforts in carrying out the learning process. Often teachers become too lazy and take learning easily because they feel students can independently learn online like now. Many teachers often do online classes at will regardless of the time. Many of them started online meetings late. In addition, teachers often give students multiple and piling assignments by providing short deadlines as well. In fact, online lessons are very burdensome for students. Often there are network problems that make them less able to get learning optimally. Therefore, teachers who are considered to be the most mature parties must be able to take the right attitude when carrying out the teaching and learning process. The learning load of students must be taken into account both materially and in time. Teachers should not only give assignments, but must carefully consider their conditions (Wahyono, Husama, \& Budi, 2020).

Online learning must be done in a timely manner. Teachers must be able to maximize learning. Always ask students whether the learning given has been maximally received or not. In addition, the teacher can of course give assignments to students to evaluate the course of learning, but the teacher must pay attention to 
the situation of students. The teacher should understand the mental condition of the student and consider the assignment he or she gives will be burdensome or not. The assignment given should be a task that is not bothersome and provides a deadline according to the difficulty level of the question. This is done so that the learning reliability is obtained properly. Miller (2020) explains that the main purpose of good online learning is to maintain as much continuity of teaching as possible, and finish the semester well as it should be.

Another thing that should be noted is the way teachers teach. Online learning that is too monotonous and long-term will be very boring for students. Teachers must be creative and create a conducive atmosphere of learning even though learning is done online. Make sure students always listen to the material that the teacher delivers so that the learning carried out does not end in vain. In addition, teachers must be able to find solutions to critical learning problems. And bargaining activities can also be tried in teaching, such as asking students for their opinions on what they want and not forgetting to ask for suggestions and input and asking students to evaluate the learning that has been done. And most importantly, teachers must pay attention to students by always reminding them to continue to learn and maintain health during this pandemic. This is done in order to make them aware and have a willingness to learn because they feel their teacher cares and does not care about them.

\section{CONCLUSION AND SUGGESTION}

The impact of Covid-19 in the course of the learning process greatly affects the education policy that is currently being established. Schools were closed and virtual classes were introduced with the help of online learning applications. The effects that students receive, especially those who carry out learning activities online, have a big impact on their mental and feelings. Most of them feel the 
negative impact related to Covid-19. In addition, both students and teachers were forced to adapt to the new policy. But for those who can take values and lessons from the Pandemic, there will be positive impacts that will be received. The current condition of the pandemic can be a reference for the spirit of every education party so that it can continue to be able to maximize the course of learning and make the best contribution in advancing the world of education with limitations.

\section{E. REFERENCES}

Bayham, J., \& Fenichel, E. P. (2020). Impact of school closures for COVID-19 on the US health-care workforce and net mortality: A modelling study. Lancet Public Health, 5(5), 271-278. Doi: https://doi.org/10.1016/S2468-2667(20)30082-7

Cao, W., Fang, Z., Hou, G., Han, M., Xu, X., Dong, J., \& Zheng, J. (2020). The psychological impact of the COVID-19 epidemic on college students in China. $\begin{array}{llll}\text { Psychiatry } \quad \text { Research, } & \text { 287, } & \end{array}$ https://doi.org/10.1016/j.psychres.2020.112934

Corbera, E., Anguelovski, I., Honey-Rosés, J., \& Ruiz-Mallén, I. (2020). Academia in the time of COVID-19: Towards an ethics of care. Planning Theory \& Practice, 21(2), 191-199. Doi: https://doi.org/10.1080/14649357.2020.1757891

De Paepe, L., Zhu, C., \& Depryck, K. (2018). Online Dutch L2 learning in adult education: Educators ${ }^{e e}$ and providerse viewpoints on needs, advantages and disadvantages. Open Learning: The Journal of Open, Distance and e-Learning, 33(1), 18-33. Doi: https://doi.org/10.1080/02680513.2017.1414586

Dyment, J., Downing, J., Hill, A., \& Smith, H. (2017). „I did think it was a bit strange taking outdoor education online ${ }^{e c}$ : Exploration of initial teacher education students ${ }^{\text {ee }}$ online learning experiences in a tertiary outdoor education unit. Journal of Adventure Education and Outdoor Learning, 18(1), 70-85. Doi: https://doi.org/10.1080/14729679.2017.1341327

Ferdiansyah, S. and Angin, R., 2020. Thai Students' Experiences of Online Learning at Indonesian Universities in the Time of the COVID-19 Pandemic. Journal of International Students, 10(3), pp.58-74. Doi: https://doi.org/10.32674/jis.v10iS3.3199 
Fitria, T., 2020. Teaching English through Online Learning System during Covid 19 Pandemic. Pedagogy: Journal of English Language Teaching, 8(2), p.138. Doi: https://doi.org/10.32332/pedagogy.v8i2.2266

Hawkley, L. C., \& Cacioppo, J. T. (2010). Loneliness matters: A theoretical and empirical review of consequences and mechanisms. Annals of Behavioral Medicine, 40(2), 218-227. DOI: https://doi.org/10.1007/s12160-010-9210-8

Ichsan, I., Rahmayanti, H., Purwanto, A., Sigit, D., Irwandani, I., Ali, A., Susilo, S., Kurniawan, E. and Rahman, M., 2020. COVID-19 Outbreak on Environment: Profile of Islamic University Students in HOTS-AEP-COVID-19 and PEBCOVID-19. Tadris: Jurnal Keguruan dan Ilmu Tarbiyah, 5(1), pp.167-178. Doi: https://doi.org/10.24042/tadris.v5i1.6283

Karkar-Esperat, T. M. (2018). International graduate students ${ }^{\text {ee }}$ challenges and learning experiences in online classes. Journal of International Students, 8(4), 1722-1735. Doi: https://doi.org/10.5281/zenodo.1468076

Li, T. and Leung, C., 2020. Exploring student mental health and intention to use online counseling in Hong Kong during the COVID -19 pandemic. Psychiatry and Clinical Neurosciences, 74(10), pp.564-565. Doi: https://doi.org/10.1111/pcn.13117

Miller, M. D. (2020, March). Going online in a hurry: What to do and where to start. The Chronicle of Higher Education, 8-10.

Moorhouse, B. L. (2020). Adaptations to a face-to-face initial teacher education course 'forced' online due to the COVID-19 pandemic. Journal of Education for Teaching. Pp. 1-3. Doi: https://doi.org/10.1080/02607476.2020.1755205

Raaper, R., \& Brown, C. (2020). The COVID-19 pandemic and the dissolution of the university campus: Implications for student support practice. Journal of Professional Capital and Community. Doi: https://doi.org/10.1108/JPCC-06-2020$\underline{0032}$

Simamora, R., 2020. The Challenges of Online Learning during the COVID-19 Pandemic: An Essay Analysis of Performing Arts Education Students. Studies in Learning and Teaching, 1(2), pp.86-103. Doi: https://doi.org/10.46627/silet.v1i2.38 
English Education: Jurnal Tadris Bahasa Inggris pISSN 2086-6003 | eISSN 2580-1449

Vol 14 (2), 2021, 320-335

Sugiyono. (2005). Memahami Penelitian Kualitatif. Bandung: ALFABETA.

Wahyono, P. \& Husamah, H. (2020). Guru profesional di masa pandemi COVID19: Review implementasi, tantangan, dan solusi pembelajaran daring. Jurnal Pendidikan Profesi Guru. Vol 1 (No 1), 51-65. doi: https://doi.org/10.22219/jppg.v1i1.12462 